\title{
BURNOUT AND ONLINE EDUCATION: ADAPTATION AND VALIDATION OF SCALE DURING PANDEMIC
}

\author{
J. Patricia Muñoz-Chávez* \\ https://orcid.org/0000-0002-8485-8594 \\ Rigoberto García-Contreras ${ }^{* *}$ \\ https://orcid.org/0000-0002-7951-9205 \\ David Valle-Cruz*** \\ https://orcid.org/0000-0002-5204-8095
}

\section{RECIBIDO: Julio 2021 / ACEPTADO: Septiembre 2021 / PUBLICADO: Enero 2022}

Como citar: Muñoz-Chávez, J. Patricia; García-Contreras, Rigoberto; Valle-Cruz, David. (2022). Burnout and Online Education: Adaptation and Validation of scale during Pandemic. Telos: revista de Estudios Interdisciplinarios en Ciencias Sociales, 24 (1), Venezuela. (Pp. 24-39).

DOI: www.doi.org/10.36390/telos241.03

\begin{abstract}
During the COVID-19 pandemic, online education represented a serious alternative to continuing working life in higher education institutions (HEls). Teachers around the world embraced a new role, adopting and using a wide range of technological and virtual tools to continue performing their activities and with the aim to interact with students and to continue teaching. For this reason, research related to seek and identify factors for the teachers' well-being is essential for educational leaders. Regarding these ideas, this paper aims to test the construct validity of a Mexican version of the Maslach Burnout Inventory-Educators Survey (MBI-ES) of Maslach et al. (1997), adapted to online education. Participants consisted of 406 Mexican university teachers who emergently switched from traditional to online educational practices during the SARS-CoV2 virus outbreak. In order to test the factor structure of three alternative models based on Szigeti et al. (2016), the authors performed exploratory and confirmatory factor analyses (Ferrando \& Lorenzo-Seva, 2018). Results showed that the model with three domain factors has the best fit. Besides, our findings show that the three-factor structure of the Mexican adaptation of MBI-ES is valid and reliable for the analysis of online education because the loading of all factors was representative.
\end{abstract}

Keywords: Burnout, Teacher, Online Education, COVID-19, Pandemic, Scale Adaptation.

\footnotetext{
* Universidad Tecnológica de la Zona Metropolitana del Valle de México. Hidalgo, México. Correo Electrónico: j.chavez@utvam.edu.mx ** Universidad Autónoma del Estado de México. Toluca, México. Correo Electrónico: rgarciac@uaemex.mx

*** Universidad Autónoma del Estado de México. Toluca, México. Correo Electrónico: davacr@uaemex.mx
} 


\section{Burnout y educación en línea: adaptación y validación de escala durante la pandemia}

\section{RESUMEN}

La educación en línea representa una alternativa a la continuidad de la vida laboral en las instituciones de educación superior (IES). Los docentes adoptaron un nuevo rol al disponer de una serie de herramientas tecnológicas y virtuales para realizar sus actividades e interactuar con los alumnos. Por esta razón, la búsqueda e identificación de factores para el bienestar de los profesores es esencial para los líderes educativos. Este trabajo tiene como objetivo probar la validez de constructo de una versión mexicana de la escala Maslach Burnout InventoryEducators Survey (MBI-ES) de Maslach et al. (1997), adaptada a la educación en línea. Los participantes consisten en 406 profesores universitarios mexicanos que cambiaron las prácticas educativas tradicionales por prácticas en línea durante la pandemia de COVID-19. Para probar la estructura factorial de tres modelos alternativos tomando como base a Szigeti et al. (2016), se realizaron análisis factoriales exploratorio y confirmatorio (Ferrando y Lorenzo-Seva, 2018). Los resultados mostraron que el modelo con tres factores de dominio tiene el mejor ajuste. Además, nuestros hallazgos muestran que la estructura de tres factores de la adaptación mexicana de MBI-ES es válida y confiable para el análisis de la educación en línea porque todas las cargas de los factores fueron representativas.

Palabras clave: Burnout, Docente, Educación en línea, COVID-19, Pandemia, Adaptación de escala.

\section{Introduction}

Nowadays, the COVID-19 pandemic has forced the world to lock down numerous economic activities (Lin et al., 2020). Governments have forced their citizens to remain in total or partial isolation, face difficulties and unexpected conditions (Cooper et al., 2020). As a result, society has faced important challenges and effects, being the education sector not the exception, and generating undesirable consequences for members who work remotely (Panisoara, et al., 2020). For instance, teachers, researchers, administrative staff, and students are isolated to preserve their safety (Hasan \& Bao, 2020). Universities face new challenges, where the educational process needs to be planned, organized, and systematized in such a way that the acquisition of knowledge is not affected and will survive this "new normality". Universities also need to face new paradigms and organizational transformations, as well as the increase in teaching activities (Chen et al., 2020).

Online education and information and communication technologies (ICTs) have become a global trend representing an indispensable tool to continue the learning process (Panisoara et al., 2020), by reducing the temporal and spatial boundaries required to stop the virus spread. Although the digital world is not new in the education sector; currently, the pandemic substantially accelerated its use and increased tensions and workloads for teachers (Rapanta, 2020). Teachers likely experience a state of physical or mental exhaustion caused by overwork or stress generated by daily confrontation with disruptive practices (Evers et al., 2004).

Teachers' mental health impacts on effective teaching and students' personal, emotional, and achievement development (Szigeti, et al., 2016). Hence, teaching is a fundamental activity with high emotional risk, and now more than ever, society requires its full 
potential. Also, this job activity represents an important element in people's lives, and in the conditions in which it is carried out, it can give meaning to the existence of workers (Guillén \& Aduana, 2008). On the other hand, it can also generate stress (Genoud et al., 2012). This phenomenon occurred in the academy, with teachers who were confronted with distance education due to the pandemic. The lack of training and resources to perform their work virtually, generated stress problems, as well as psychosocial consequences and risks that resulted in burnout problems (Prado-Gascó et al., 2020), which has a high emotional component (Suárez \& Martín, 2019).

Burnout is a psychological response to work-related stress, and it is characterized by emotional exhaustion, depersonalization, and feelings of low personal accomplishment (Maslach et al., 2001). Previous studies have shown the predictive capability of burnout in features as workers health and productivity, and its impact in several contexts as health area, firms, and education (Castelló et al., 2017; Maslach et al., 2001; Szigeti et al., 2016).

Although several instruments are developed to measure burnout, the most widely used is the Maslach Burnout Inventory (Maslach et al., 1997). Initially, MBI was created for people who worked in human services and consisted of 25 items for measuring four dimensions: emotional exhaustion, depersonalization, lack of personal accomplishment, and involvement. However, its factor structure was modified; for instance, Maslach et al., (1997) excluded the involvement dimension and reduced the scale to 22 items. In addition, there are some variants of $\mathrm{MBI}$ (e.g., MBI-GS, MBI-HSS and MBI-ES). Specifically, one of them refers to people working in education, who are among the professionals most prone to Burnout syndrome (Rodríguez \& Sánchez, 2018). The MBI-Educators Survey (MBI-ES) by Maslach et al. (1997), which specifies that the assisted people are students and covers three subscales or dimensions mentioned above (McCormack \& Cotter 2013). All items are positively worded, and the three subscales have a high correlation with each other (Leiter \& Maslach, 2017).

In recent years, the prevalence of burnout in the educational sector and among teachers has gained importance (McLean et al., 2019). In this regard, Szigeti et al., (2016), identified studies showing a prevalence between 5 and 30\%; meanwhile, Villaverde et al., (2019) indicated that the prevalence of the syndrome in teachers in Mexico in recent years ranges from $35.5 \%$ to $53.1 \%$. Thereafter, several studies have been conducted on burnout syndrome in teachers, in terms of its prevalence and correlation with other variables. Among those carried out recently, we found the research by Silva et al., (2018), who determined the prevalence of burnout, depression, and the correlations among this phenomenon, depression, socio-demographic and organizational variables. In this sense, Chang (2020), using structural equations, examined the relationships between the full-time teachers' beliefs, about the rules of emotional deployment in the classroom, the regulation of emotions and post-burnout feelings. Likewise, Moè, \& Katz (2020), examined the mediating role of the psychological needs of teachers and burnout. Likewise, McLean et al., (2019), examined the extent to which burnout and self-efficacy as teacher-level variables explained the variance in universal screening scores.

Inside the specific literature about teachers' burnout during the COVID-19 pandemic, few studies were found. For instance, Prado-Gascó et al., (2020), analyzed the perception of COVID-19 and the psychosocial risks of non-university teachers comparing Spain and Mexico. Matiz et al., (2020), evaluated with self-report instruments, one month before and one month after the start of the pandemic lockdown measuring burnout levels, mindfulness skills, empathy, personality 
profiles, interceptive awareness, psychological well-being, and emotional distress. Panisoara et al., (2020), analyzed burnout and technostress conducting research on the intention to continue online education during the pandemic, which represents a significant stressor to support teachers in coping with the contingency. Fabbro et al., (2020), explored the effects of mindfulness meditation on both, teachers' self-reported personality traits and their perceived stress and burnout. They used the Maslach MBI to measure teachers' burnout considering, the MBI global scores and the emotional exhaustion subscale. Additionally, Chen et al., (2020) conducted a study of 483 Chinese university teachers, where they examined the influence of professional identity on burnout during the pandemic, as well as the moderating effect of job satisfaction of these variables. The results indicated that professional identity and satisfaction are negative predictors of burnout and job satisfaction moderates professional identity and burnout.

As mentioned above, since the implementation of the quarantine, online education has been the way to keep the teacher-student instructional process. However, the sudden change has represented an imbalance for teachers. In this regard, De Oliveira et al., (2020), pointed out that online and distance education in times of pandemic generates stress and anguish due to uncertainty and excess information. In addition, Estrada-Muñoz et al., (2020), showed the relevance of measuring the manifestations of psychosocial risks and adverse effects on teachers because the expanded use of ICTs in education has generated techno-stress because of the lack of adaptation to the technological environment. Furthermore, Hodges et al., (2020) found that teachers experience stress derived from the isolation generated by COVID-19 and the practical and technical challenges that teachers face when preparing and teaching classes from home, which in many cases lack technical support.

Although, there is evidence of studies related to teacher stress and burnout during the COVID-19 period; only one of those identified (Chen et al., 2020) has used the Maslach Burnout Inventory (MLB-ES). The others rely on documentary methods or other measurement instruments (p. e., RED-TIC questionnaire). Consequently, this study aims is to test the construct validity of the Mexican version of MBI-ES that was adapted to online education. Data were collected through a sample of 406 university teachers who switched to the remote teaching modality since the quarantine setup.

To test the internal structure of the construct, an exploratory factor analysis (EFA) and a confirmatory factor analysis (CFA) were performed. To test the factor structure, three measurement models of the MBI-ES adapted to online education were evaluated. The models correspond to Maslach et al. (2001) original three-factor structure and Szigeti et al., (2016) suggested two-factor and an observed construct structure (Figure 1). 
Figure 1. Measurement Models of MBI-ES Adapted to Online Education

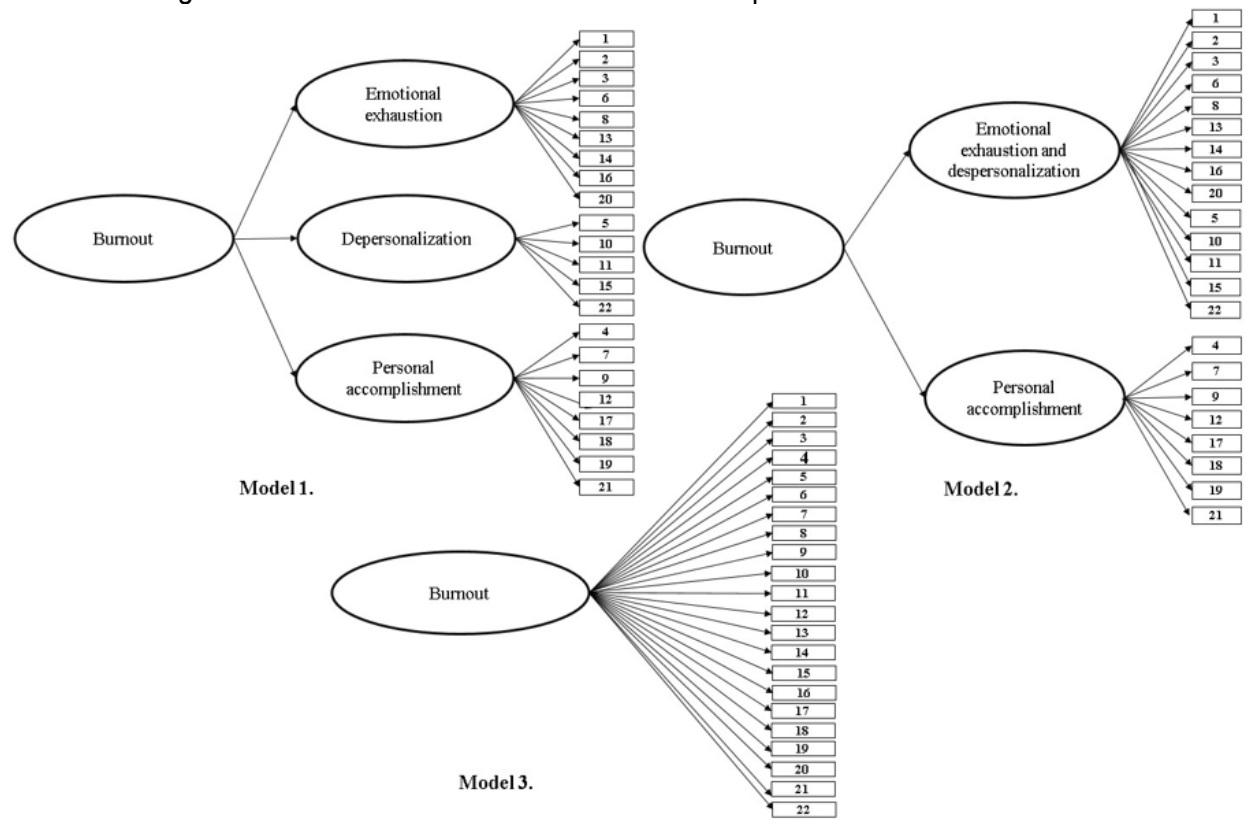

Source: Authors' elaboration.

\section{Methods}

\section{Participants and Procedure}

The empirical study was performed through cross-sectional research on a nonprobability and for convenience sampling. The sample was comprised of 406 university teachers who have lived and worked in Mexico during the pandemic disease lapse and have had to change from their habitual process to an online education. Participation in the study was voluntary and anonymous and participants were informed about the study. Data collection consisted of a survey distributed by e-mail and digital media. The response time was approximately 10 minutes. All participants gave their consent.

A total of 406 teachers from different Mexican universities participated, of which 230 $(56.7 \%)$ were females and $176(43.3 \%)$ were males. The mean age of respondents was 42.9 years $(S D=11.5) .39 .7 \%$ of the participants had bachelor's degree or Engineering, $36.7 \%$ had a Master's degree, and $23.6 \%$ had a Ph.D. degree. $66.7 \%$ of the surveyed teachers belong to public universities and $33.3 \%$ to private universities. In terms of seniority in the university, the highest percentage $(40.4 \%)$ were newcomers and had less than 5 years in the university, $19.5 \%$ from 6 to 10 years, $14.3 \%$ from 11 to 15 years, $13.1 \%$ from 16 to 20 , and $12.8 \%$ had more than 20 years of service. Finally, most of the sample $(76.6 \%)$ reported not feeling comfortable with the remote teaching. 


\section{Measures}

\section{Alternative Maslach Burnout Inventory-Educators Survey}

Teacher's burnout in times of COVID-19 was assessed with a Mexican version modified of MBI-ES (Maslach et al., 1997). The instrument consisted of 22 items and three factors (Table 1): (1) Emotional exhaustion was measured by nine items, including, for some example: "I feel that working with my students virtually all day long is a great effort and tires me out" and "I think I work too much with this new teaching method"; (2) Depersonalization is measured by five items, for example: "I have become more insensitive to people since I have been involved with the online education process" and "During this period of online education, I am not really concerned about what happens to my students", and (3) Personal accomplishment is measured by eight items, with a sample of items: "I easily understand how my students feel with the online education process" and "I feel energized by online education. The measurement ranges for all items were between 0 ("never") and 6 (always).

Table 1. MLB-ES Dimensions

\begin{tabular}{|c|c|c|}
\hline Dimension & Definition & Operationalization \\
\hline Emotional exhaustion & $\begin{array}{l}\text { Represents the feeling of } \\
\text { being emotionally overloaded } \\
\text { with tasks (Fernet et al., } \\
\text { 2017), thus, experiencing an } \\
\text { exhaustion (Plieger et al., } \\
\text { 2015) and a progressive loss } \\
\text { of energy to perform the job } \\
\text { and consequently physical } \\
\text { and mental exhaustion (Silva } \\
\text { et al., 2018). }\end{array}$ & $\begin{array}{l}\text { It assesses the experience of } \\
\text { being emotionally exhausted } \\
\text { by the demands of work. } \\
\text { Nine items: } 1,2,3,6,8,13 \text {, } \\
14,16,20 \\
\text { Maximum score: } 54 \text { points }\end{array}$ \\
\hline Depersonalization & $\begin{array}{l}\text { Refers to the deterioration of } \\
\text { the ability to relate to other } \\
\text { people (Silva et al., 2018), or } \\
\text { distancing with users (Fabbro } \\
\text { et al., 2020), manifested } \\
\text { through negative or } \\
\text { excessively detached } \\
\text { attitudes (Fernet et al., 2017), } \\
\text { and even rejection towards } \\
\text { them, bureaucratizing the } \\
\text { relationship. (Patlán, 2013). }\end{array}$ & $\begin{array}{l}\text { It assesses the degree to } \\
\text { which each teacher } \\
\text { recognizes attitudes of } \\
\text { coldness and aloofness. } \\
\text { Five items: } 5,10,11,15,22 \\
\text { Maximum score: } 30 \text { points }\end{array}$ \\
\hline Personal accomplishment & $\begin{array}{l}\text { Implies a negative self- } \\
\text { judgment of personal } \\
\text { capabilities and relation with } \\
\text { demands to be met, loss of } \\
\text { interest, worsening of self- } \\
\text { esteem and self-confidence } \\
\text { (Silva et al., 2018), as well as }\end{array}$ & $\begin{array}{l}\text { Evaluates feelings of self- } \\
\text { efficacy and self-fulfillment at } \\
\text { work. } \\
\text { Eight items: } 4,7,9,12,17,18 \text {, } \\
\text { 19, } 21\end{array}$ \\
\hline
\end{tabular}




\begin{tabular}{|l|l|l|}
\hline & $\begin{array}{l}\text { isolation in the task, } \\
\text { irritability, dissatisfaction with }\end{array}$ & Maximum score: 48 points \\
oneself and reduced & \\
& satisfaction with work \\
achievements (Patlán, 2013). & \\
\hline
\end{tabular}

Source: Authors' elaboration.

\section{Data Analysis}

SPSS version 24 for EFA and AMOS version 23 for CFA were used for data analysis. Inside the EFA, a main component analysis was performed. Additionally, a Kaiser-Meyer-Oklin (KMO) sample adequacy and Bartlett's sphericity test indexes were calculated. The Varimax method was used for the rotation factor.

The CFA was performed with the structural equation modeling (SEM) to estimate the degree of goodness to fit the three suggested models (one-factor model, two-factor model, and three-factor model). The Chi-Square test was performed to evaluate the fit of models of the statistical ratio of verisimilitude. However, since the chi-square is sensitive to the sample size (Hair et al., 2008), the following statistics of fit were included: (1) Comparative Fix Index (CFI); (2) Tucker-Lewis Index (TLI); (3) Root Mean Squared Error of Approximation (RMSEA); (4) Cfit RMSEA that evaluates the statistical deviation of RMSEA ( $p<0.05)$; (5) Goodness of Fit Index (GFI). The values ranging between 0.90 and 0.95 or higher for CFI TLI, GFI are considered acceptable to excellent. An RMSEA below 0.05 indicates an excellent fit, between 0.05 and 0.08 indicates an acceptable fit and above 0.10 indicates a poor fit. (Kline, 2011; Yu, 2002). Subsequently, reliability was estimated with the internal consistency tests (Cronbach's alpha and McDonald's omega). Values equal to or higher than 0.70 for alpha and 0.73 for omega are acceptable (Reidl-Martínez, 2013; Viladrich et al., 2017).

\section{Results}

\section{Items Analysis}

Regarding skewness and kurtosis, it was observed that, according to the frequency, 11 items showed values among \pm 1.00 and 11 items showed values among \pm 2 . About the importance, all items showed values among \pm 2 . Outliers were not identified; therefore, the results can be generalized (Hair et al., 2008).

\section{Exploratory Factorial Analysis (EFA)}

A series of exploratory and confirmatory factor analyses were conducted to find the best structure and fitting model for the Mexican adaptation of MBI-ES.

The factorial structure obtained by the analysis exploratory (EFA) yielded three components as Maslach et al., (1997) proposal. All variable loads or saturation were higher than 0.50 (Brown, 2015) and an explained variance of $67.68 \%$. (Table 2). KMO statistic was evaluated within a range of 0 to 1 . The result reports a KMO $=0.912$ ("very good"). Bartlett's sphericity test resulted in a significant test of $p<0.01$ (Ferrando \& Lorenzo-Seva, 2018). The above allowed for an adequate sample (Table 2). 
Table 2. Exploratory Factorial Analysis (EFA) of Measurement Models of MBI-ES Adaptation

\begin{tabular}{|l|c|c|}
\hline \multicolumn{1}{|c|}{ Model } & \multicolumn{1}{|c|}{ Number of factors } & \multicolumn{2}{|c|}{0.67685} \\
\hline $\begin{array}{l}\text { Model } 1 \text { (Maslach Three-factors } \\
\text { et al., 2001) }\end{array}$ & & \multicolumn{2}{|c|}{0.57500} \\
\hline $\begin{array}{l}\text { Model 2 (Szigeti et Two-factors } \\
\text { al., 2016) }\end{array}$ & \multicolumn{2}{|c|}{0.38624} \\
\hline $\begin{array}{l}\text { Model 3 (Szigeti et } \\
\text { al., 2016) }\end{array}$ & One-factor & \multicolumn{2}{|c|}{ Components } \\
\hline \multicolumn{1}{|c|}{ Principal component analysis (rotated matrix) } \\
\hline
\end{tabular}




\begin{tabular}{|c|c|c|c|}
\hline $\begin{array}{l}\text { have been involved in the } \\
\text { online education process }\end{array}$ & & & \\
\hline $\begin{array}{l}11 . \quad \text { I think that online } \\
\text { education is making me } \\
\text { emotionally tough }\end{array}$ & & & 0.718 \\
\hline $\begin{array}{l}\text { 12. I feel energized by online } \\
\text { education }\end{array}$ & & 0.602 & \\
\hline $\begin{array}{l}\text { 13. I feel frustrated in my job } \\
\text { with this method }\end{array}$ & 0.728 & & \\
\hline $\begin{array}{l}\text { 14. I think I work too much } \\
\text { with this new teaching } \\
\text { method }\end{array}$ & 0.746 & & \\
\hline $\begin{array}{l}\text { 15. In this period of online } \\
\text { education I am not really } \\
\text { concerned about what } \\
\text { happens to my students }\end{array}$ & & & 0.708 \\
\hline $\begin{array}{l}\text { 16. Working online with } \\
\text { students causes me stress }\end{array}$ & 0.772 & & \\
\hline $\begin{array}{l}\text { 17. I feel that I can easily } \\
\text { create a comfortable virtual } \\
\text { learning environment }\end{array}$ & & 0.828 & \\
\hline $\begin{array}{l}\text { 18. I feel motivated after } \\
\text { working virtually with } \\
\text { students }\end{array}$ & & 0.813 & \\
\hline $\begin{array}{l}\text { 19. I feel that I get a lot of } \\
\text { valuable things out of online } \\
\text { education }\end{array}$ & & 0.817 & \\
\hline $\begin{array}{l}\text { 20. I feel finished with online } \\
\text { education process, at the } \\
\text { limit of my possibilities }\end{array}$ & 0.756 & & \\
\hline $\begin{array}{l}\text { 21. Since I have been } \\
\text { working online, I deal with } \\
\text { emotional problems very } \\
\text { calmly }\end{array}$ & & 0.687 & \\
\hline $\begin{array}{l}\text { 22. With this method I think } \\
\text { students blame me for some } \\
\text { of their problems }\end{array}$ & & & 0.533 \\
\hline $\begin{array}{l}\text { KMO }=0.912 \\
\text { Bartlett's test }(p<0.01)\end{array}$ & & & \\
\hline
\end{tabular}

Source: Authors' elaboration.

\section{Confirmatory Factor Analysis (CFA)}

After the EFE, several confirmatory factors were analyzed to approve the representativeness of factors and find the best fitting measurement model of the MBI-ES Mexican adaptation. The fit indices of the three-alternative models' proposals are presented in Table 3. Model 1 (three-factor model) was the only one that yielded an RMSEA value equal to 0.08 . Therefore, the model with three domain factors showed the best fit of the proposed models. Also, 
the analysis yielded CFI, TLI, and GFI values close and above to 0.90 , so the fit of Model 1 is acceptable.

Table 3. Confirmatory Factorial Analysis (CFA) of Measurement Models of MBI-ES Adaptation

\begin{tabular}{|l|c|c|c|c|c|c|c|c|}
\hline Measurement models & $\mathbf{X}^{\mathbf{2}}$ & $\mathbf{D f}$ & RMSEA & Cfit $\mathbf{p}$ & $\mathbf{C F I}$ & TLI & GFI & BIC \\
\hline $\begin{array}{l}\text { Model 1. Three-factor } \\
\text { model (Maslach et al., } \\
\text { 2001) }\end{array}$ & $463.27^{* *}$ & 206 & 0.08 & $<0.01$ & 0.89 & 0.87 & 0.91 & 1309 \\
\hline $\begin{array}{l}\text { Model 2. Two-factors } \\
\text { model (Szigeti et al., } \\
2016)\end{array}$ & $843.27^{* *}$ & 208 & 0.10 & $<0.01$ & 080 & 0.80 & 0.83 & 1686 \\
\hline $\begin{array}{l}\text { Model 3. One-factor } \\
\text { model (Szigeti et al., } \\
\text { 2016) }\end{array}$ & $1026.59^{* *}$ & 209 & 0.11 & $<0.01$ & 0.77 & 0.75 & 0.79 & 2880 \\
\hline
\end{tabular}

Notes. $X^{2}=$ Chi-square; $d f=$ Degrees of freedom; ${ }^{* *}=(p<0.01)$; RMSEA $=$ Root mean square error of approximation; Cfit $p=$ Closeness of fit RMSEA; $\mathrm{CFI}=$ Comparative fit index; TLI = Tucker-Lewis index; $\mathrm{GFI}=$ Goodness of fit index .

Source: Authors' elaboration.

Table 4 shows the standardized factor loadings of Model 1. All items loaded significantly for each dimension of the MBI-ES proposal. All factors of emotional exhaustion ( 9 items) showed standardized weights regression $(p<0.01)$ between 0.65 and 0.87 ; factors of depersonalization $(5$ items) standardized weights regression $(p<0.01)$ between 0.45 and 0.83 , and factors of personal accomplishment standardized weights regression $(p<0.01)$ between 0.42 and 0.90 . Table 4 shows the items in the short form for presentation purposes, but the full items are shown in the Table 2.

Table 4. Standardized Factor Loading of Measurement Model MBI-ES Adaptation

\begin{tabular}{|l|c|c|c|}
\hline \multicolumn{1}{|c|}{$\begin{array}{c}\text { Items } \\
\text { (Short form) }\end{array}$} & $\begin{array}{c}\text { Emotional } \\
\text { exhaustion }\end{array}$ & Depersonalization & $\begin{array}{c}\text { Personal } \\
\text { accomplishment }\end{array}$ \\
\hline 1. I feel emotionally drained & 0.85 & & \\
\hline 2. I feel tired & 0.84 & & \\
\hline $\begin{array}{l}\text { 3. When I wake up, I feel } \\
\text { fatigued }\end{array}$ & 0.84 & & \\
\hline $\begin{array}{l}\text { 6. Attending students virtually is } \\
\text { a great effort and tires me out }\end{array}$ & 0.74 & & \\
\hline $\begin{array}{l}\text { 8. Online education is wearing } \\
\text { me out }\end{array}$ & 0.87 & & \\
\hline 13. I feel frustrated & 0.76 & & \\
\hline 14. I think I work too much & 0.65 & & \\
\hline $\begin{array}{l}\text { 16. Working online causes me } \\
\text { stress }\end{array}$ & 0.75 & & \\
\hline 20. I feel finished & 0.77 & & \\
\hline
\end{tabular}




\begin{tabular}{|c|c|c|c|}
\hline $\begin{array}{l}\text { 5. Students as if they were } \\
\text { impersonal objects }\end{array}$ & & 0.64 & \\
\hline 10. I have become insensitive & & 0.78 & \\
\hline $\begin{array}{l}\text { 11. is making me emotionally } \\
\text { tough }\end{array}$ & & 0.83 & \\
\hline $\begin{array}{l}\text { 15. I am not really concerned } \\
\text { about what happens to my } \\
\text { students }\end{array}$ & & 0.50 & \\
\hline $\begin{array}{l}\text { 22. Students blame me for some } \\
\text { of their problems }\end{array}$ & & 0.45 & \\
\hline 4. I understand my students & & & 0.42 \\
\hline $\begin{array}{l}\text { 7. I deal very effectively with my } \\
\text { students' problems }\end{array}$ & & & 0.57 \\
\hline $\begin{array}{l}\text { 9. I am positively influencing the } \\
\text { lives of my students }\end{array}$ & & & 0.68 \\
\hline 12. I feel energized & & & 0.62 \\
\hline $\begin{array}{l}\text { 17. I can easily create a } \\
\text { comfortable environment }\end{array}$ & & & 0.77 \\
\hline 18. I feel motivated & & & 0.90 \\
\hline 19. I get a lot of valuable things & & & 0.90 \\
\hline $\begin{array}{l}\text { 21. Since I have been working } \\
\text { online }\end{array}$ & & & 0.62 \\
\hline McDonald's omega & 0.943 & 0.906 & 0.963 \\
\hline Cronbach's alpha & 0.935 & 0.771 & 0.885 \\
\hline
\end{tabular}

Source: Authors' own elaboration.

Finally, the internal consistency analyses were performed by McDonald's omega and Cronbach's alpha methods. Both are recommended for multidimensional constructs (Viladrich et al., 2017). Coefficients for both omega and alpha were satisfactory according to the criteria mentioned above (Reidl-Martínez, 2013; Viladrich et al., 2017). In this regard, the reliability coefficients exceed the critical value of 0.70 for each dimension (Table 4); specifically, the coefficients are as follows: (1) Emotional exhaustion ( $\omega=0.943 ; a=0.935)$; (2) Depersonalization $(\omega=0.906 ; \alpha=0.771)$, and (3) Personal accomplishment $(\omega=0.963 ; \alpha=0.885)$.

\section{Discussion}

Burnout syndrome has been the subject of numerous studies since the end of the last century. Scientific findings have observed different effects depending on the performance area of each profession. The pandemic, caused by the SARS-CoV-2 virus has confined individuals at home regardless of their gender, income, occupation and responsibilities (Barrios et al., 2021), and this sense, generated the emerging implementation of distance education causing health effects because of improvisation, lack of technological capabilities, excessive workload, employment uncertainty, and the disconnecting impossibility. 
For this reason, the current scenario of online education has the potential of triggering and generating mental health affectation. This situation requires a direct and critical follow-up by the literature in the field of teachers' mental health. Pandemic conditions propitiated an extremely difficult work environment, motivating the appearance of reactions that put physical and mental well-being at risk (Saltijeral \& Ramos, 2015).

Moreover, the multiple challenges that teachers face, in addition to working with numerous people, propitiates stress to a greater extent - compared to other types of activities due to the affective and emotional burden involved (Ansley et al., 2021; Ruiz-Rodríguez et al., 2017). In the work environment, pressure is inevitable, even if it is well dosed, it can be a catalyst for good performance. However, burnout arises from a high-stress load and pressure that is excessive or difficult to control (Leka et al., 2004). For many teachers, online education during the COVID-19 pandemic has meant this kind of scenario.

Regarding the models' tests, the three-factor structure of the MBI-ES is widely valid and accepted. In this regard, the results showed that all the items loaded significantly for the factors. EFA showed high factorial weights (higher than 0.60) for all items, except for item 22 (0.533). However, it remains representative for the dimension (personal accomplishment) and MBI-ES. Besides, CFA has confirmed the representativeness of items for the factorial structure. All items showed factorial weights above 0.60 , except for four items $(4,7,15$, and 22), nevertheless, they are representative of the construct (Brown, 2015).

Therefore, the study of the internal structure (exploratory and confirmatory analyzes) and reliability were satisfactory. The above responds to the original scale developed and supports the structure proposed for this study. Likewise, findings add to the literature an alternative due to the proposal's scope, which allows describing the feeling of burnout of the university teachers who suddenly switched to remote education after the quarantine period. In this sense, it is important for university leaders to timely identify the feelings of their teachers in times of crisis, since although they understand the need to modify their work dynamics, feelings of concern, uncertainty and as lack of teaching efficacy come in to play and they may resent it emotionally (Sokal et al., 2020).

\section{Conclusions}

This research aimed to test the Mexican version of MBI-ES adapted to the online work. The study used exploratory and confirmatory factor analyses to test the factor structure of three alternative models. Despite the literature, we found for the MBI-ES, the results confirm the initial configuration of the Maslach Burnout Inventory. Also, minor modifications were performed to adapt the MLB-ES to online education during the COVID-19 pandemic.

The education sector routinely experiences high levels of stress and burnout, due to the demands inherent to their work. However, the COVID-19 pandemic increased the demands, as it sped up the transition to digital teaching. Teachers faced various technical and practical challenges due to technological, contextual, and personal factors that can negatively affect their well-being and job performance.

The foregoing ideas highlights the relevance of measuring the psychosocial risks manifestations in online education during pandemics. This study tested the construct validity of the Mexican version of MBI-ES, adapted to online education. Furthermore, this paper provides an option to measure the psychosocial risks manifestations, allowing educational leaders to 
detect the prevalence of the phenomenon to establish timely and healthy coping strategies for the benefit of teachers, students, and the institution.

This study has some limitations. First, the sample size (relatively small) suggests careful consideration of conclusions, hence, a larger sample is necessary. Second, the crosssectional design cannot set up the generality of the results and needs to test the measures in different times and contexts. Third, during the COVID-19 pandemic period, data were collected through an online questionnaire, and there could be bias, although the results are coincident with previous research. Finally, for this study, the MBI-ES was adapted for online education. The results are satisfactory; however, several studies must prove the proposal to corroborate its validity and reliability.

\section{References}

Ansley, Brandis; Houchins, David; Varjas, Kris; Roach, Andrew; Patterson, DaShaunda; Hendrick, Robert. (2021). The impact of an online stress intervention on burnout and teacher efficacy. Teaching and Teacher Education, 98, England. https://doi.org/10.1016/j.tate.2020.103251

Barrios, Yisel; Galindo, Luis; Argüelles, María del Carmen; Chacón, Dennis. (2021). Improving COVID-19 response: redirecting risk communication efforts towards equity issues. Revista Latinoamericana de Difusión Científica, 3(5), Venezuela. (Pp. 3-8). Available in:

http://www.difusioncientifica.info/index.php/difusioncientifica/article/view/29

Brown, Timothy (2015). Confirmatory factor analysis for applied research (Second edition). Guilford Publications. United States.

Castelló, Monserrat; McAlpine, Lynn; Pyhältö, Kirsi. (2017). Spanish and UK post-PhD researchers: Writing perceptions, well-being and productivity. Higher Education Research and Development, 36 (6), Australasia. (Pp. 1108-1122). https://doi.org/10.1080/07294360.2017.1296412

Chang, Mei Lin. (2020). Emotion display rules, emotion regulation, and teacher burnout. Frontiers in Education, 5 (90), Switzerland. (Pp. 1-11). https://doi.org/10.3389/feduc.2020.00090

Chen, Huaruo; Liu, Fan; Pang, Liman; Liu, Fei; Fang, Tingting; Wen, Ya; Chen, Shi; Xie, Zhiyao; Zhang, Xuehui; Zhao, Yihong; Gu, Xueying. (2020). Are You Tired of Working amid the Pandemic? The Role of Professional Identity and Job Satisfaction against Job Burnout. International Journal of Environmental Research and Public Health, 17 (24), Switzerland. (Pp. 1-14). https://doi.org/10.3390/ijerph17249188

Cooper, lan; Modal, Argha; Antonopoulos, Chris. (2020). A SIR model assumption for the spread of COVID-19 in different communities. Chaos, Solitons Fractals, 139, Australia. https://doi.org/10.1016/i.chaos.2020.110057

De Oliveira Araujo, Francisco Jonatan; Abrantes de Lima, Ligia Samara; Martins Cidabe, Pedro Ivo; Bezerra Nobre, Camila; Rolim Neto, Modesto Leite. (2020). Impact Of Sars-Cov-2 and Its Reverberation In Global Higher Education And Mental Health. Psychiatry Research, 288, Netherlands. https://doi.org/10.1016/.psychres.2020.112977

Estrada-Muñoz, Carla; Castillo, Dante; Vega-Muñoz, Alejandro; Boada-Grau, Joan. (2020). Teacher Technostress in the Chilean School System. International Journal of 
Environmental Research and Public Health, 17 (15), Switzerland. (Pp. 1-17). https://doi.org/10.3390/ijerph17155280

Evers, Will; Tomic, Welco; Brouwers, André. (2004). Burnout among teachers: students'and teachers' perspectives compared. School Psychology International, 25 (2), England. (Pp. 131-148). https://doi.org/10.1177/0143034304043670

Fabbro, Anastacia; Fabbro, Franco; Capurso, Viviana; D’Antoni, Fabio; Crescentini, Crescentini. (2020). Effects of Mindfulness Training on School Teachers' Self-Reported Personality Traits As Well As Stress and Burnout Levels. Perceptual and Motor Skills, 127 (3), United States. (Pp. 515-532). https://doi.org/10.1177/0031512520908708

Fernet, Claude; Chanal, Julien; Guay, Frédéric. (2017). What fuels the fire: Job- or task-specific motivation (or both)? On the hierarchical and multidimensional nature of teacher motivation in relation to job burnout. Work \& Stress, 31(2), England. (Pp. 145-163). https://doi.org/10.1080/02678373.2017.1303758

Ferrando, Pere; Lorenzo-Seva, Urbano. (2018). Assessing the Quality and Appropriateness of Factor Solutions and Factor Score Estimates in Exploratory Item Factor Analysis. Educational and Psychological Measurement, 78(5), United States. (Pp.762-780). https://doi.org/10.1177/0013164417719308

Genoud, María Andrea; Broveglio, Gerardo; Picasso, Emilio. (2012). Motivaciones laborales en empresas productivas y servuctivas en Ciudad Autónoma de Buenos Aires (CABA) y Gran Buenos Aires (GBA) (Argentina). Estudios Gerenciales, 28 (123), Colombia. (Pp. 65-84). https://doi.org/10.1016/S0123-5923(12)70205-X

Guillén Mondragón, Irene; Aduna Mondragón Alma Patricia. (2008). La influencia de la cultura y del estilo de gestión sobre el clima organizacional. Estudio de caso de la mediana empresa en la Delegación Iztapalapa. Estudios Gerenciales, 24 (106), Colombia. (Pp. 47-64). https://doi.org/10.1016/S0123-5923(08)70031-7

Hair, Joseph; Anderson, Rolph; Tatham, Ronald; Black, William. (2008). Análisis Multivariante (Fifth edition). Prentice Hall. España.

Hasan, Najmul; Bao, Yukun. (2020). Impact of "e-Learning crack-up" perception on psychological distress among college students during COVID-19 pandemic: A mediating role of "fear of academic year loss". Children and Youth Services Review, 118, United States. https://doi.org/10.1016/i.childyouth.2020.105355

Hodges, Charles; Moore, Stephanie; Lockee, Barb; Trust, Torrey; Bond, Aaron. (2020). The difference between emergency remote teaching and online learning. EDUCAUSE Review, United States. Retrieved from: https://bit.ly/3b0Nzx7

Kline, Rex. (2011). Principles and Practice of Structural Equation Modeling. (Third edition). Guilford Publications. United States.

Leka, Stavroula; Griffiths, Amanda; Cox, Tom. (2003). Work organisation and stress: systematic problem approaches for employers, managers and trade union representatives. World Health Organization. United Kingdom.

Leiter, Michael; Maslach, Christina. (2017). Burnout and engagement: Contributions to a new vision. Burnout Research, 5, Netherlands. (Pp. 55-57). https://doi.org/10.1016/j.burn.2017.04.003

Lin, Jiabao; Li, Lei; Luo, Xin; Benitez, Jose. (2020). How do agribusinesses thrive through complexity? The pivotal role of ecommerce capability and business agility. Decision 
Burnout and Online Education: Adaptation and Validation of scale during Pandemic

Support Systems, 135, Netherlands. $\quad$ (Pp. 1-13). https://doi.org/10.1016/j.dss.2020.113342

Maslach, Christina; Jackson, Susan; Leiter, Michael. (1997). MBI: The Maslach burnout inventory manual. Consulting Psychologists Press. Palo Alto, United States.

Maslach, Christina; Schaufeli, Wilmar; Leiter, Michael. (2001). Job bornout. Annual Review of

Psychology, 52, United States. (Pp. 397-422),

https://doi.org/10.1146/annurev.psych.52.1.397

Matiz, Alessio; Fabbro, Franco; Paschetto, Andrea; Cantone, Damiano; Paolone, Anselmo;

Crescentini, Cristiano. (2020). Positive Impact of Mindfulness Meditation on Mental Health of Female Teachers during the COVID-19 Outbreak in Italy. International Journal of Environmental Research and Public Health, 17 (18), Switzerland. (Pp. 1-22). https://doi.org/10.3390/ijerph17186450

McCormack, Nancy; Cotter Catherine. (2013). Managing Burnout in the Workplace. A Guide

for Information Professionals. Chandos Publishing. Cambridge, United Kingdom.

McLean, Deija; Eklund, Katie; Kilgus, Stephen; Burns, Matthew. (2019). Influence of teacher burnout and self-efficacy on teacher-related variance in social-emotional and behavioral screening scores. School Psychology, 34 (5), United States. (Pp. 503511), https://doi.org/10.1037/spq0000304

Moè, Angelica; Katz, Idit. (2020). Self-compassionate teachers are more autonomy supportive and structuring whereas self-derogating teachers are more controlling and chaotic: The mediating role of need satisfaction and burnout. Teaching \& Teacher Education, 96, United States. (Pp. 1-9). https://doi.org/10.1016/j.tate.2020.103173

Panisoara, Ion Ovidiu; Lazar, lulia; Panisora, Georgeta; Chirca, Ruxandra; Ursu, Anca Simona. (2020). Motivation and Continuance Intention towards Online Instruction among Teachers during the COVID-19 Pandemic: The Mediating Effect of Burnout and Technostress. International Journal of Environmental Research and Public Health, 17 (21), Switzerland. (Pp. 1-28). https://doi.org/10.3390/ijerph17218002

Patlán, Juana. (2013). Efecto del burnout y la sobrecarga en la calidad de vida en el trabajo.

Estudios Gerenciales. 29 (129), Colombia. (Pp. 445-455).

https://doi.org/10.1016/i.estger.2013.11.010

Plieger, Thomas; Melchers, Martin; Montag, Christian; Meermann, Rolf; Reuter, Martin. (2015).

Life stress as potential risk factor for depression and burnout. Burnout Research, 1

(2), Netherlands. (Pp. 19-24). https://doi.org/10.1016/i.burn.2015.03.001

Prado-Gascó, Vicente; Gómez-Domínguez, María; Soto-Rubio, Ana; Díaz-Rodríguez, Luis;

Navarro-Mateu, Diego. (2020). Stay at home and teach: A comparative study of psychosocial risks between Spain and Mexico during the pandemic. Frontiers in Psychology, 11, Switzerland. (Pp. 1-12). https://doi.org/10.3389/fpsyg.2020.566900

Rapanta, Chrysi; Botturi, LLuca; Goodyear, Peter; Guàrdia, Lourdes; Koole, Marguerite. (2020). Online University Teaching During and after the Covid-19 Crisis: Refocusing Teacher Presence and Learning Activity. Postdigital Science and Education, 2, Switzerland.

(Pp. 923-945). https://doi.org/10.1007/s42438-020-00155-y

Reidl-Martínez, Lucy María. (2013). Confiabilidad en la medición. Investigación en Educación Médica, 2 (6), México. (Pp. 107-111). https://doi.org/10.1016/S2007-5057(13)72695-4 
Ruiz-Rodríguez, Paloma; Cano-Vindel, Antonio; Navarro, Roger; Medrano, Leonardo; Moriana, Juan Antonio; Aguado, Carlos; ... \& de Investigación PsicAP, G. (2017). Impacto económico y carga de los trastornos mentales comunes en España: una revisión sistemática y crítica. Ansiedad y Estrés, 23 (2-3), España. (Pp. 118-123). https://doi.org/10.1016/i.anyes.2017.10.003

Rodríguez Flores, Eduardo Antonio; Sánchez Trujillo, María de los Ángeles. (2018). Síndrome de Burnout y variables sociodemográficas en docentes de una universidad privada de Lima. Revista de Investigación Educativa, 36 (2), España. (Pp. 401-419). http://dx.doi.org/10.6018/rie.36.2.282661

Saltijeral Méndez, María Teresa; Ramos Lira, Luciana. (2015). Identificación de estresores laborales y burnout en docentes de una secundaria para trabajadores del Distrito Federal. Salud mental, 38 (5), México. (Pp. 361-369). Available in: https://www.redalyc.org/pdf/582/58243957008.pdf

Silva, Nilson Rogério; Bolsoni-Silvall, Alessandra Turini; Loureiro, Sonia Regina. (2018). Burnout síndrome and depression in Elementary school teachers: A correlational study. Revista Brasileira de Educacao, 23, Brasil. (Pp. 1-18). http://dx.doi.org/10.1590/S1413-24782018230048

Sokal, Laura; Trudel, Lesley; Babb, Jeff. (2020). Canadian teachers' attitudes toward change, efficacy, and burnout during the COVID-19 pandemic. International Journal of Educational Research Open, 1. United Kingdom. Article in press. https://doi.org/10.1016/i.jiedro.2020.100016

Suárez Martel, María José; Martín Santana, Josefa. (2019). Influencia del perfil sociodemográfico del profesorado universitario sobre la inteligencia emocional y el burnout. Educación XX1, $22 \quad$ (2), España. (Pp. 93-117). https://doi.org/10.5944/educxx1.22514

Szigeti, Réka; Balázs, Noémi; Bikfalvi, Réka; Urbá, Róbert. (2016). Burnout and depressive symptoms in teachers: Factor structure and construct validity of the Maslach Burnout inventory-educators survey among elementary and secondary school teachers in Hungary. Stress and Health, 33 (1), England. (Pp. 530-539). https://doi.org/10.1002/smi.2737

Viladrich, Carme; Angulo-Brunet, Ariadna; Doval, Eduardo. (2017). Un viaje alrededor de alfa y omega para estimar la fiabilidad de consistencia interna. Anales De Psicología, 33 (3), España. (Pp. 755-782). https://doi.org/10.6018/analesps.33.3.268401

Villaverde, Diego; Unda, Sara; Escotto, Eduardo; Flores, Rosa. (2019). Personality Traits that Predict the Burnout Syndrome on Mexican Teachers. Propósitos y $\begin{array}{llllll}\text { Representaciones, } & 7 & \text { (3), } & \text { Perú. } & \text { (Pp. } & \text { 41- }\end{array}$ http://dx.doi.org/10.20511/pyr2019.v7n3.346

Yu, Ching-Yun. (2002). Evaluating Cutoff Criteria of Model Fit Indices for Latent Variable Models with Binary and Continuous Outcomes. Doctoral Dissertation. Ph.D. in Education. University of California. United States. (Pp. 1-68). Available in: https://www.statmodel.com/download/Yudissertation.pdf 